\title{
Arraying institutional layers in federalism reforms: lessons from the German case
}

\author{
Nathalie Behnke and Sabine Kropp ${ }^{b}$

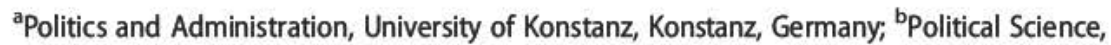 \\ Freie Universität Berlin, Berlin, Germany
}

\begin{abstract}
The introductory article to this Special Issue offers an analytical framework for investigating federal reforms. By looking through the lens of institutional theory, it provides an avenue for grasping the basic mechanisms which are at work in reform processes. It is argued that the German case which comprises three distinct reform steps stretching out over more than one decade represents an especially suitable example for understanding the general logics of federal reform. As a "prototype" of sequential, asynchronous reforms, it allows for generating theoretical insights beyond the findings of a single case study. The article reveals that layering, sequencing, and the linkage of different arenas are the most relevant aspects to be considered when examining federal reforms. Finally, it is established how the contributions to this Special Issue refer to the analytical categories worked out in this introduction.
\end{abstract}

KEYWORDS Federalism reform; institutional theory; sequencing; layering; incongruity

\section{The German federalism reform in comparative perspective}

Germany, as one of the established federal democracies, is currently looking back to a decade of ongoing federalism reforms. Whereas the first constitutional reform finished in 2006 aimed at disentangling joint decision-making and effectively transferred a number of legislative responsibilities to the German Länder, the second reform stage finished in 2009 introduced the debt brake as a guarantor of the federal entities' fiscal responsibility and concomitantly established a stability council supervising their budgetary discipline. A major reform of the highly contested fiscal equalization scheme had initially been envisaged for the first stage, but was then shelved to the second and postponed again to some indefinite later time. Finally, since 2014, minister presidents and finance ministers of the Länder have been preparing proposals 
renegotiating the fiscal relations for a third step of federalism reform with a result still pending at the time of this writing. As a minimal solution, the Bundestag and Bundesrat can simply extend the validity of the current laws due to expire in 2019. There is a fair chance, however, for getting a reform law passed by parliament by the upcoming federal elections in 2017, which would then - albeit preliminarily - conclude a decade of stepwise federalism reform.

As a real-life laboratory of a long-term debate on reforming established federal institutions and norms, this process aroused considerable interest among federalism scholars. Similar to other federal reform processes in established federation ${ }^{1}$ as well as in emerging or transforming federal structures, ${ }^{2}$ the analysis of such continuing, sequential reforms helps to better grasp the inherent logic of federal reforms in general. The German case offers prolific evidence on the institutions that are being changed, the normative discourses employed to promote particular reform directions, and the role of different actors involved. Accordingly, research on the German reform process focuses on details of the issues at stake and their likely consequences. This includes for example the redistribution of legislative responsibilities in the first reform stage (Georgii and Borhanian, 2006; Höreth, 2007; Burkhart et al., 2008), a critical evaluation of the debt brake and concomitant provisions of administrative cooperation in the second phase (Baus, 2007; Feld, 2010; Kastrop et al., 2010), and controversial analyses of the principles and techniques stipulating how to distribute and redistribute public revenues among the federal units in the third reform step (Geißler et al., 2015). Other contributions are dedicated to actors and the normative arguments they employ to promote their preferred vision of the reform (Münch and Zinterer, 2000; Hrbek, 2003). A steadily growing strand of literature addresses the (more or less limited) dynamics of the reforms by offering particular explanations as to why such a big effort has resulted in such little change (Benz, 2005; Sturm, 2010; Schneider, 2013). Fritz W. Scharpf's notion of the joint decision trap (Scharpf, 1985, 2009; Auel, 2008; Benz, 2008) has probably been the explanation most frequently invoked when reasoning about the limited output and impact of the reform efforts (for a critique see Benz, 2005, 2008).

In spite of the numerous accounts on the issue, no encompassing analysis examining the complete sequence of reform steps has ever been offered so far. This research gap becomes all the more relevant, as it is particularly the long-term perspective which allows gaining a more precise understanding of the mechanisms that lie at the heart of developments of federal institutions and processes. Actually, federal dynamics has marked the cutting edge of comparative federalism scholarship in recent years (Gerber and Kollman, 2004; Benz and Broschek, 2013b; Bolleyer et al., 2014). One noteworthy insight stemming from comparative analyses of 
constitutional reforms in federal states is that change, continuity, and stability interact (Benz and Broschek, 2013a). The absence of change looks like stability only superficially, but it leads to stalemate and, ultimately, to the rupture of systems.

More precisely, the institutional complexity inherent in the federal architecture and the plurality of interests and positions involved make frequent adaptations necessary in order to sustain the stability of the system (Behnke and Benz, 2009). In addition to federal reforms, institutional, political, and jurisdictional safeguards help to balance centripetal and centrifugal dynamics (Bednar, 2009). Furthermore, mechanisms facilitating an ongoing dialogue between conflicting interests are an essential requisite for securing longterm federal stability without stalemate (Tully, 1995; Hueglin, 2000), a concept which Charles Taylor describes as "procedural liberalism" (Taylor, 1992).

In this context, we conceptualize federal reforms as formal and legally fixed provisions which respond to political, social, and economic dynamics by adapting and changing the institutional setting. Once enacted, however, they take on a life on their own: they affect other subsystems, trigger dynamics, and demand new institutional modifications. Germany is an especially illustrative case in point, since the reform was split up into three distinct stages. This particular dynamic becomes obvious in that decisions made in one round triggered new problems and created institutional tensions, to which actors responded with institutional adaptations and corrections in the next round of the reform. This piecemeal approach finally led to a meandering - not to say inconsistent - reform path, which, for its part, graphically illuminates the interdependence between institutional adaptation and stability. In this sense, a framework for analysing federal reforms must account for the mechanisms that maintain long-term stability through change or through adaptation of the differential features constituting the federal system.

This Special Issue contributes to gaining a deeper understanding of the outlined puzzle. By providing a common analytic framework for all contributions containing relevant variables for studying and explaining the initiation, development and consequences of long-term territorial reform processes, this introduction enables generalization beyond the German case and further advances our understanding of the mechanisms of federal reforms. Moreover, as the contributions assembled in this Special Issue study the reform process from different perspectives, a more complete picture of the federal dynamics caused by the sequential reforms is drawn. At the end of this introductory framework, it is briefly sketched how the contributions in this Special Issue echo the elements of this theoretical perspective in their analyses. 


\section{Understanding the dynamics of federal reforms - elements of an analytical framework}

Federal systems are more frequently subject to constitutional reforms than their unitary counterparts (Lorenz, 2011). It is inherent in the nature of federal systems that they continually produce tensions and frictions which demand institutional adaptations (Benz and Broschek, 2013a). Hence, they are disposed to reform, although they are characterized by a high number of veto points which may lead to deadlock and stalemate.

While actors initiate change because of a rational motivation to solve problems or to improve their relative positions, the effects of those changes often produce unintended consequences and spill-overs as well as creating frictions or incompatibilities with other unchanged institutional layers, thus making adaptive reforms necessary to redress the frictions (Pierson, 2000b). Furthermore, rational motives may overlap with ideological ones, and ideas about the best world of federalism may change over time or with changing political majorities (Lieberman, 2002). The ensuing pattern is far from an unambiguous causal relationship between motive and result. The puzzle which calls for an explanation is thus not the fact that federal reforms are initiated and enacted at all, that is, not the fact of institutional change per se, but rather it is the sequential structure, the "layering" of reforms and the inconsistent or piecemeal approach to reforms over time. The framework developed here is meant to provide the ingredients for a systematic analysis of this inconsistent and stepwise reform path.

Even though institutionalist theories are sometimes said to explain stability better than change (Schmidt, 2008), the institutional perspective is useful in analysing federal reforms insofar as institutions substantially structure actors' role orientations, preferences, and interactions. Those actors are constrained by the existing institutions and produce outcomes which may themselves alter a given institutional framework. This account is very close to what Fritz W. Scharpf termed "actor-centred institutionalism" (ACI) (Mayntz and Scharpf, 1995; Scharpf, 1997). In our framework, however, we adhere to the broader institutionalist perspective (Hall and Taylor, 1996; Nee, 2005; Scott, 2014) which provides useful notions for investigating degrees, pace, and directions of change. This contribution upholds the focus on actors pursuing individual preferences as drivers and subjects of change that refers to Scharpf's ACl as well as Rational Choice Institutionalism in general (Shepsle, 2006). In addition, by focusing on the procedural nature of reforms which extend over a longer period of time and are marked by sequences, we employ the "historic" perspective distinctive of Historical Institutionalism (HI) (Mahoney et al., 2009). HI was traditionally more concerned with explaining the absence of change by notions such as path dependency (Pierson, 2000a) than by the extent or direction of change. In recent years, however, 
scholars of $\mathrm{HI}$ have developed a fine-tuned conceptual tool-kit to analyse processes of institutional changes stretching along longer time-spans (Orren and Skowronek, 1994; Lieberman, 2002; Pierson, 2004; Mahoney and Thelen, 2010; Broschek, 2011). The "multiple-orders approach" (Orren and Skowronek, 1994; Broschek, 2011) emphasizes the multi-dimensionality of complex institutional frameworks such as federal constitutions. Those different layers can embody incompatible logics, thus creating a mismatch and frictions as well as a permanent pressure for adjustment (Broschek, 2011: 540). Also, the role of ideas in shaping the content and direction of institutional change was conceptualized and integrated in the institutionalist framework (Lieberman, 2002). The solutions that actors envisage for perceived problems have been largely influenced by the visions or normative ideas they hold about the state of the world. Again, as such ideas are put into practice in federal reforms, this may produce discontinuities and incompatibilities that drive adaptive change (Lieberman, 2002: 698).

As regards the role of ideas in the institutional reform process, an important debate among institutionalist scholars revolves around the question whether the ideas guiding actors are endogenous or exogenous to the explanatory framework (Lieberman, 2002; Farrell and Héritier, 2007: 701): Should they be an integral part of the analysis or are they something of a residual explanatory variable resorted to when other explanations fail? In the sequential account to federal reforms, this is not an "either-or question". Rather, the extended time span of the process suggests that both will be the case. On the one hand, people change their opinions in reaction to outcomes they observe (in that case, ideas are endogenous to the process). On the other hand, external developments may support particular visions and thus contribute to changing majorities among advocates of a special vision or idea (exogenous, changing the decision situation for the actors).

Based on this broader institutionalist perspective, we further elaborate on the building blocks of analysis: the actors of reform; the role of ideas; the triggers and layers of reform causing particular reform dynamics; and the content, direction, and mode of reform in order to take into account not only the formal, but also the substantial aspects of change. In the final section of this introduction, we sketch how the contributions to this Special Issue make use of the analytical categories in building their explanations.

\subsection{Actors of reform}

All types of institutionalism acknowledge the crucial role of actors in triggering, negotiating, and enacting institutional changes. Actors need to perceive a necessity or opportunity for institutional change and they must have an incentive to enact change in a certain direction. Incentives may come from cost-benefit-calculations or from ideological persuasion (or both). In 
institutionalist analyses, actors are mostly treated as complex actors, in which internal processes of preference formation are neglected (Scharpf, 2000: 101105). Relevant actors in federal reforms are executives (government and administration) as well as parliaments of federal entities holding a mix of interests. Länder governments, for example, pursue specific interests of their individual Land, of a group of Länder (e.g. Eastern vs. Western or rich vs. poor Länder) or of the entirety of Länder towards the federal level. Those interests that are tied to the status and structural properties of a territory intersect with party political interests of the governing coalitions. Parties are thus another group of relevant actors, because they usually set the electoral and legislative agenda. In comparative federalism studies, the relationship between party politics and territorial dynamics is an influential field of research. Parties, either statewide, nationalist, or regionalist, have been identified as the main drivers of territorial change (Meguid, 2005; Swenden and Maddens, 2009; Toubeau and Massetti, 2013). Sometimes, constitutional courts act as initiators or brokers of reforms. But also elites, citizens, and associations address specific demands to federal institutions (Erk, 2008). If their expectations do not match the functioning of given institutions, then dynamics can be triggered either from "below" or from "above".

While actors are the main drivers of institutional change, they are just as much affected by it. Institutional changes can alter actor constellations, attitudes, and behaviour of individual as well as organizational structures of collective actors. Federal reforms often generate new majorities and reshape actor constellations in addition to sculpting the internal structure of organizations. Having gained more rights of self-rule or shared rule, parliaments and executives of federal entities usually establish new committees or routines of information processing, of internal, horizontal, and vertical coordination. Parties need to adapt their internal organizations to the changing territorial power allocation. If social, political, and economic asymmetries increase, then parties need to grant their regional branches greater autonomy, thereby setting up processes which lead to the emergence of a more regionalized party system (Detterbeck, 2012). When parties recalibrate their internal structures to processes of regionalization, the result can be a perpetuated dynamic of decentralization (Hombrado, 2011; Petersohn et al., 2015) or at least a continued negotiation on how to balance unity and diversity (Hueglin, 2013). Like other European democracies, Germany has undergone such development of its party system, albeit to a smaller degree. Research has observed a growing diversification of the regional party systems which has generated multi-coloured Länder coalition governments. As a consequence, majorities often need to be negotiated in the Bundesrat, which makes joint decision-making less calculable for the federal government, but enhances flexibility by dissolving the logic of the formerly bipolar party competition (Kropp, 2010). 


\subsection{The role of ideas}

While most actors in federal states may agree on the general virtues of a federal state architecture as opposed to the unitary state one, they still hold utterly distinct views on the basic ontological question: e pluribus unum how much diversity or unity is desired and acceptable for the federal entity, and what does this diversity and unity refer to? Responses to this problem essentially shape the content and direction of reforms.

In multi-ethnic states, for example, the problem of balancing unity and diversity is most acute. It raises the questions as to which levels of individual vs. group rights are suitable for sustaining the stability of the federation, how federal units are adequately represented in federal processes, or which degree of autonomy they should possess (Gagnon and Tully, 2001; Choudhry, 2008). Even in largely homogenous societies, this tight relationship needs to be permanently calibrated. The German federal reform provides rich material for illustrating how challenging this task may become. Although the values of unity and equality are clearly placed over diversity and are reflected in various constitutional principles such as federal loyalty ("Bundestreue") or the equivalence of living conditions ("Gleichwertigkeit der Lebensverhältnisse"), the question of how to translate "equivalence" of living conditions into federal practice has recurrently been subject to conflict and redefinition.

If federations undergo piecemeal reforms, then prevalent normative ideas can be toned down or even replaced by alternative ones during the reform period. The German case perfectly illuminates the fact that the ideological underpinnings of proposals have changed several times. The first reform stage was dominated by the ideas of disentanglement, competition, autonomy, and dual federalism. An encompassing actor coalition of most parties, influential think tanks, and the federal as well as the governments of the donor Länder promoted those ideas. An ideological macro-trend - the neoliberal market ideology promoting economic efficiency through competition and a withdrawal of the state - coincided with material interests of the donor Länder. The German unification had increased the number of recipient Länder from 5 to 11 and changed the political interests of the federal government which claimed more leeway in legislation (i.e. less influence of the Bundesrat) for enacting large-scale reforms. Some noteworthy adjudications of the federal constitutional court with their concomitant normative weight supported the shift towards disentanglement.

The second step, which in 2009 introduced the debt brake and the stability council, was deeply imprinted by the experience of the European economic, fiscal, and debt crisis. Hence, budgetary austerity and economic stability were broadly promoted as the leitmotiv of reform. The federal government was setting the pace, while the voices warning about the negative economic effects of strict austerity were being ignored. The ensuing German and 
European "debt brakes" put additional pressure on the federal and the Länder governments. The restrictions put on the income side met increasing demands on the expense side, mainly due to the steadily increasing burden of social security expenses, but also because of the recent expansion of Länder tasks introduced by the first reform stage. The tightened financial leeway was, however, felt with differing intensity and contributed more to exacerbating the existing vertical and horizontal fiscal imbalance in Germany. The growing divide fuelled debates about which kind and degree of unity was to be pursued and generated disputes as to how the costs of unity should be distributed among the federal units. The second step thus heralded the third one which was designed to reassess the fiscal equalization scheme, which, in any case, became inevitable as the relevant fiscal laws will run out at the end of 2019. Currently, the idea of solidarity regains weight in the public debate, but it is far from being undisputed. Headed by Bavaria, a small but powerful coalition of the donor states strives for reducing the level and extent of fiscal equalization payments, arguing with the principles of autonomy and ability. At the same time, counter to the 2006 reform, some contested decisions which had implemented elements of dual federalism are being acknowledged as dysfunctional and were abrogated again.

\subsection{Reform dynamics: triggers and layers}

The interplay between actors and ideas helps to explain how, when, or under which circumstances federal reforms are triggered and unfold over time. Very generally, the existing institutional structure must be inefficient or dysfunctional to spark attempts at reform. However, the faulty working of an institution is not an objective matter of fact. It is not discovered by a calculation rule or undisputedly stated by a group of experts. Rather, actors judge the existing order as inadequate. This evaluation is permeated by beliefs and prevailing ideas and possibly influenced by diffusing institutional models which have gained interpretative authority.

It may happen, for example, that a group of actors holding a specific idea about the federal institutional structure gains more bargaining power and can thus press for reforms. They regard institutions as dysfunctional because the existing allocation of jurisdictions and responsibilities between federal units no longer mirrors their real power. Similarly, decision-making processes are considered as dysfunctional if they produce either abundant negotiation costs which result in deadlocks and delayed decisions due to the number of veto players involved (Buchanan and Tullock, 1962), or if they cause excessive external costs, involving decisions at the cost of minorities. Those perceptions are often caused by shifts of economic power, the socio-structural composition, and the political resources of groups. 
In another scenario, external political developments contribute to a change in public opinion which brings together different groups of actors advocating a specific direction of change. The global financial crisis beginning in 2008 , for instance, seriously undermined the legitimacy of neo-liberal ideas and gave notions like solidarity an - albeit limited - boost. Moreover, in European countries, the EU works as a constant source of institutional adaptation. Over the past decades all institutional and administrative settings have had to undergo encompassing processes (Börzel and Risse, 2003; Radaelli, 2003). External changes in the perception about the (dys-)functionality of the existing institutional structure may also be triggered by the incongruity of policy issues. As multi-level systems distribute power among different levels and territorial or non-territorial units (see for example McGarry and Moore, 2005), policy problems regularly intersect territorial or functional borders. When federal institutions impair the principle of congruity between those jurisdictions taking a decision and those which are affected by a decision (Benz and Sonnicksen, 2015; Kropp, 2015), reforms may aim at rescaling policies so that the boundaries of jurisdictions coincide better with their fiscal responsibilities and effects.

Finally, apart from questions of power of groups or external pressure for adaptation, existing institutions may be perceived to conflict with democracy because they blur accountability. Then, reforms may be triggered by different groups of actors, elites, the population, parties, or individual governments with the aim of restoring legitimacy by re-establishing more clear-cut accountabilities in the territorial structure. As federal systems provide strong veto points, they are reliant on consensus-building mechanisms and negotiations running through informal channels which make the formal institutions work. As such, federal institutions tend to obscure responsibilities and, consequently, are perceived as being opaque and prone to elite capture (Kropp, 2015). Due to the complex distribution of responsibilities, voters in federal systems often do not react to decisions at the level where they are made, but rather address demands and protest to the authorities of other jurisdictions. It may therefore become one of the major goals of reform to restore legitimacy by re-adapting decisionmaking structures to the boundaries of demoi. This sometimes implies such complex challenges as boundary shifting and authority migration (Gerber and Kollman, 2004).

Often, the changes achieved themselves become triggers for new rounds of negotiations, thus making the sequence of reform steps an important category for analysis. Different "layers" of a federal system can simultaneously or asynchronously be subject to just one or sometimes to even several changes. New rounds of reform are triggered if changes in institutions, power distributions, or actor constellations call for adapting other layers of the federal structure (Benz and Broschek, 2013a: 5ff.) ${ }^{3}$ or if the changes result in tensions 
between formal and informal institutions. Later reforms can consequentially refine and reinforce erstwhile reforms; they can deviate from an already existing reform path, take up remaining topics or contradict them. Hence: timing, sequencing, layering, and the linkage of arenas prove to be the most relevant aspects to be considered when analysing reform processes (Braun, 2009; Benz and Sonnicksen, 2015). Analytically, however, it is sometimes hard to distinguish when one sequence ends and the next begins since reforms do not always consist of clear-cut, consistent phases.

Sequential reforms, as realized in the German case, are prone to generate meandering or even inconsistent reforms if its different stages are guided by divergent or perhaps conflicting principles, or if they modify different institutional layers which, again, trigger adaptive or restorative change in other layers. Vice versa, even though one reform sequence may suggest that it generates an encompassing change, an assessment of the whole reform can reveal that the federal institutional setting remains nonetheless on the established historical path. The German case thus offers deep and generalizable insights in the multi-directional and multi-layered effects of federalism reform.

\subsection{Substance of reforms: content, direction, and extension}

Federal reforms typically re-allocate power distributions and responsibilities for specific issues among various levels of government. Power and responsibilities comprise jurisdictions (legislative, executive, and judicial); financial resources and fiscal responsibilities (tax levying or tax varying powers and tax distribution); representation and modes of decision-making (such as quotas or reserved seats in parliament, veto rights or rights of co-decision, unanimity vs. majority rule, and the number and proportion of actors involved). Power distributions can shift horizontally, that is, from symmetry to asymmetry and vice versa, or vertically, that is, towards increasing centralization or decentralization. Still, the centralization-decentralization dimension cannot sufficiently capture degrees of change in self-rule or shared rule (Petersohn et al., 2015). While federal reforms may empower actors differentially, this may lead to new interest coalitions and trigger counter-movements in order to re-balance the power distribution.

In this sense, the duration, extent, and direction of results are also of relevance for the overall reform dynamic. In the German reform, we recurrently observe that formal reforms were later redressed either by superseding legislation, by adjudication of the constitutional court or by administrative practice. This shows that the distinction between formal and informal change is partially artificial, as processes of informal change often end in formal reforms and vice versa. Formal change is said to occur when it emerges as the result of institutionalized processes which alter norms at constitutional level, while informal change comes about by re-interpretations of existing norms, adaptation of 
routines or changes of norms at sub-constitutional and extra-legal level (Behnke and Benz, 2009; Benz and Colino, 2011; Lorenz, 2011), and is diagnosed when it takes place away from the surface of formal federalism reforms.

Similarly, the extent of reforms itself can explain further reform dynamics. Formal change often just leads to piecemeal adaptation due to the complexity of issues at stake. It is easier to evoke consensus among negotiation partners on single issues rather than on all encompassing reform packages. The failed constitutional convention in Austria is a good example for illuminating a reform process in which the complexity of interwoven topics could not be handled in the given time frame (Behnke, 2010). Such piecemeal approaches, on the other hand, trigger subsequent reforms, as due to the tight interrelation between policy issues, responsibilities, and resources, changes of one aspect of the federal structure usually spill over to others. A change in fiscal relations (e.g. tax allocation or equalization payments), for instance, cannot be neatly separated from the discussion about the allocation of and the financial responsibility for tasks. Reversing this argument, it can be assumed that connecting issues in reform debates offers opportunities for package deals and can thus contribute to avoiding deadlock.

\section{Analysing federalism reform dynamics: insights from the contributions to this special issue}

In highlighting different aspects of the ten years long federalism reform in Germany, the contributions to this Special Issue fill the analytic categories introduced in the preceding section with empirical evidence. Perspectives on the topic focus on historical (Benz) and immediate (Stecker) antecedents; they investigate the consequences and outcomes (Dose and Reus; Stecker; Korioth) and explore the sequences and layers of the process (Kropp and Behnke; Benz). Several contributions devote particular attention to the actors of the reform. Whereas Detterbeck examines the changing mode of the German federal party system, Stecker as well as Dose and Reus focus on the German Länder. Others investigate how ideas transformed into reform results, that is, which substantial answers were given to the basic question of how to balance unity and diversity (Stecker; Dose and Reus; Korioth). Finally, the contribution of Lorenz puts the German case in comparative perspective, thereby embedding the empirical findings into a broader context. In terms of the theoretical elements provided by this framework, the contributions present relevant findings and set the scene for a broader comparative perspective.

The role of different actors or actor coalitions and their interests in triggering reforms is analysed in all contributions. Main actors were the federal and Länder governments and parliaments (Stecker; Dose and Reus; Kropp and Behnke), the political parties (Detterbeck), the constitutional court (Korioth) 
as well as municipal umbrella organizations (Kropp and Behnke), think tanks, single experts, and societal pressure groups (Benz). Stecker elaborates on the significance of actor coalitions, showing that it was not the institutional provisions alone which caused the (dys-)functionality of an institution, but rather the strategic use actors make of it. Most prominent actors were the reform commissions during the first and second reforms. Composed of representatives of the federal and the Länder levels, of parliamentarians and the executive under the dual leadership of the two major parties, they mirrored almost exactly the cleavages of German federalism (Detterbeck) which formed an "octagon" consisting of East and West German Länder, of rich and poor ones, of federal and common Länder interests, and of party cleavages. At the third reform stage, in contrast, no commission was established. Instead, the negotiations on future fiscal relations have been conducted within the existing intergovernmental bodies mainly composed of either the minister presidents or the finance ministers. They proceed in a completely informal manner largely secluded from the public.

Most contributions identify ideas as the main triggers of reform. As noted above, those ideas considerably changed over the stages of the reform process, with the first reform stage being dominated by arguments highlighting the perceived dysfunctionality of existing federal institutions. Stecker highlights that the German federalism with its numerous veto points and, in particular, the strong legislative participation of the Bundesrat was identified as a basic cause for slow and incremental decision-making. Kropp and Behnke show how an informal coalition of the economically and financially powerful Länder, neo-liberal academics, and think tanks successfully challenged the ideational foundation of equivalent living conditions by advocating disentanglement and the model of dual federalism as a promising solution. Korioth elucidates how the Federal Constitutional Court changed its current ruling concerning financial solidarity towards more autonomy of the Länder. Regardless of lawyers' opinions which alerted decision-makers to the fragmentation of law and increasing asymmetries as consequences of the reform, the new distribution of legislative responsibilities allowed for greater variation in policy-making across the Länder due to a longer catalogue of exclusive legislative responsibilities or deviation rights from federal legislation. The effects of this paradigmatic shift on policy-making varieties are investigated by Dose and Reus who spell out the scope and consequences of the reform.

In the second and third reform steps, the triggering role of ideas was less explicitly pronounced than in the first. While the relevant political and societal actors at all levels of government made use of a similar rhetoric, the reform content and direction marked a move away from the competitive and dual federalism ideal of the first reform step. Accordingly, Korioth points out that the second reform step, which led to the establishment of the debt brake and the stability council, was guided by the model of fiscal austerity. His 
article reveals that the Länder no longer pursued the goal of autonomy, but were rather willing to accept increased involvement and control of the federal government in exchange for financial support. Finally, in the third reform step aimed at reforming fiscal relations in the federal system, the article of Kropp and Behnke reveals how the basic ideas of federalism partially returned to the notion of solidarity and joint responsibility.

Responding to the shifting models guiding the reform sequences, actors reversed the content and direction of reform from one stage to the next. Stecker analyses the reform of legislative competences by looking into changes of shared rule in the Bundesrat. Indeed, the number of approval laws in the Bundesrat decreased. Accordingly, as Dose and Reus show, policy fragmentation in fields of devolved legislative responsibilities increased slightly. The second reform step, in contrast, strengthened the federal government by establishing the stability council and the debt brake. From the perspective of constitutional law, Korioth illustrates how the debt brake and the stability council question the Länder's exclusive jurisdictions. In terms of administrative procedures and joint tasks, this led to a remarkable re-entanglement, partly reversing the initiatives of the first reform step (Kropp and Behnke). The third stage is aimed exclusively at unwinding fiscal entanglements, readjusting the tax distribution, and simplifying the equalization scheme. Whether this will lead to more centralization or to a decentralization of fiscal jurisdictions is to date still an open question. While no final compromise has been struck yet, first agreements among the Länder show a unanimous tendency towards a "verticalization" of fiscal transfers. That is, the Länder are willing to trade in a part of their (anyway strongly limited) fiscal autonomy in exchange for receiving greater and more reliable financial support from the federal level - a solution which would clearly work in favour of centralization.

The contributions come to divergent assessments of the extent of change. In its strictest terms, the reform package of 2006 was the most comprehensive constitutional reform since the adoption of the Basic Law in 1949. In substance, though, it did not effectively alter the substance of intertwined federalism. Even though a limited number of responsibilities were disentangled and transferred to the state or the federal level (Dose and Reus), the reform did not extensively move the federal system towards the pole of dual federalism, something which Benz criticizes in his contribution. Similarly, Korioth blames the second step as mainly symbolic politics and questions its effectivity in limiting new deficits.

In several contributions, a long-term perspective of constitutional reform is taken (Kropp and Behnke; Lorenz; Benz) which pays particular attention to aspects of timing, sequence, and layering. Kropp and Behnke explain the zigzag pattern of the stepwise reform across the three stages - from disentanglement to re-entanglement - by pointing out that initially one layer of the federal system - the allocation of responsibilities - had been changed, but was not 
accompanied by a concomitant transfer of fiscal duties. This generated an institutional incongruity which in itself called for subsequent reforms to remedy the inconsistencies. In her comparative analysis, Lorenz argues that frequency and scope of reforms depend on a country's constitutional culture, something which can be attributed to the tradition of shared rule federations on the one hand and dual federations on the other hand. Shared rule federations are shaped by a collaborative interaction style, and actors prefer explicit constitutional agreements. Both characteristics facilitate frequent amendments. As Germany is categorized as a shared rule federation, the relative frequency of constitutional reforms as well as the cooperative interaction mode is consistent with her argument. Taking on the perspective of $\mathrm{HI}$, Benz maintains that the German reform process can best be understood from a long-term perspective. According to his analysis, the insufficient reform result is owed to path dependent institutions, particularly to contradicting developments of visions and institutions, some of which worked in favour of unity and some of which were in favour of diversity. Benz highlights that these contradictions have for centuries called for mechanisms appropriate to overcome tensions; they have given rise to the practice of negotiation and governing by consensus and thus have strengthened inter-administrative relations.

The contributions assembled in this Special Issue provide some generalizable features of federalism reform which can be fruitful for further comparative research. The German case is a striking - not to say extreme (Gerring, 2008) case representing a sequential, asynchronous reform attempt. As such, it reveals that layering, sequencing, and the linkage of different arenas are the most relevant aspects when federations undergo institutional reforms. It exemplarily demonstrates that reforms confined to one institutional layer trigger dynamics in others and that synchronous changes in various layers interact, sometimes producing unintended outcomes. All these elements play a role in other reform processes as well, albeit in various combinations and to different degrees. Considering this inherent logic of federalism reforms, it becomes evident why many of them need to be readjusted after a while, be it formally or by applying informal adaptations. As institutionalized attempts which respond to existing change and set up new developments, federal reforms usually represent just one chapter in a long-term horizon of federal dynamics.

\section{Notes}

1. Examples are the long-lasting constitutional reform debate in Canada (Russell, 2004) or the constitutional reforms in Switzerland (1987-2004) and in Austria (2002-2005) with varying success (Freiburghaus, 2002; Bußjäger, 2004; Braun, 2009; Behnke, 2010).

2. Examples are the devolution policy in the UK (Bradbury and Mitchell, 2005; Jeffery, 2009; Keating and McEwen, 2005; Mitchell, 2009) or the series of 
constitutional reforms in Belgium (Poirier, 2002; Hooghe, 2003; Swenden et al., 2006; De Winter and Baudewyns, 2009; Deschouwer, 2009).

3. Benz and Broschek (2013a: 8) distinguish four federal layers, which they call "societal", "institutional", "normative/ ideational", and "constellation of actors". Those factors are all contained in our analytic framework as well, either as triggers for change or as elements of change. Therefore, we can directly build on their very useful notion of "layers".

\section{Acknowledgements}

We would like to thank the two reviewers for their thoughtful comments on this paper.

\section{Disclosure statement}

No potential conflict of interest was reported by the authors.

\section{References}

Auel, K. (2008), Still no exit from the joint decision trap: the German federal reform(s), German Politics, Vol.17, No.4, pp.424-439.

Baus, R. (ed) (2008), Föderalismusreform II: Weichenstellungen für eine Neuordnung der Finanbeziehungen im deutschen Bundesstaat. Baden-Baden: Nomos.

Bednar, J. (2009), The Robust Federation. Principles of Design. Cambridge: Cambridge University Press.

Behnke, N. (2010), Föderalismusreform in Deutschland, der Schweiz und Österreich, in J. v. Blumenthal and S. Bröchler (eds), Föderalismusreform in Deutschland. Bilanz und Perspektiven im internationalen Vergleich (pp.37-58). Wiesbaden: VS-Verlag.

Behnke, N. and Benz, A. (2009), The politics of constitutional change between reform and evolution, Publius: The Journal of Federalism, Vol.39, No.2, pp.213-240.

Benz, A. (2005), Kein Ausweg aus der Politikverflechtung? - Warum die Bundesstaatskommission scheiterte, aber nicht scheitern musste, Politische Vierteljahresschrift, Vol.46, No.2, pp.204-214.

Benz, A. (2008), From joint decision traps to over-regulated federalism: adverse effects of a successful constitutional reform, German Politics, Vol.17, No.4, pp.440-456.

Benz, A. and Broschek, J. (2013a), Introduction, in A. Benz and J. Broschek (eds), Federal Dynamics: Continuity, Change and Varieties of Federalism, pp.i.E. Oxford: Oxford University Press.

Benz, A. and Broschek, J. (eds) (2013b), Federal Dynamics. Oxford: Oxford University Press. Benz, A. and Colino, C. (2011), Constitutional change in federations - a framework for analysis, Regional \& Federal Studies, Vol.21, No.4-5, pp. 381-406.

Benz, A. and Sonnicksen, J. (2015), Federalism and democracy - compatible or at odds with one, in C. Fraenkel-Haeberle, S. Kropp, F. Palermo and K.-P. Sommermann (eds), Citizen Participation in Multi-Level Democracies. Leiden: Brill Nijhoff.

Bolleyer, N., et al. (2014), A theoretical perspective on multi-level systems in Europe: constitutional power and partisan conflict, Comparative European Politics, Vol.12, No.4, pp.367-383.

Börzel, T.A. and Risse, T. (2003), Conceptualizing the domestic impact of Europe, in K. Featherstone and C. M. Radaelli (eds), The Politics of Europeanization, pp.57-80. Oxford: Oxford University Press. 
Bradbury, J. and Mitchell, J. (2005), Devolution: between governance and territorial politics, Parliamentary Affairs, Vol.58, No.2, pp.287-302.

Braun, D. (2009), Verfassungsänderung trotz vieler Veto-Spieler: Föderalismusreform in der Schweiz, in T. Bräuninger, S. Shikano and J. Behnke (eds), Jahrbuch für Handlungs- und Entscheidungstheorie, pp.87-118. Wiesbaden: VS Verlag.

Broschek, J. (2011), Conceptualizing and theorizing constitutional change in federal systems: insights from historical institutionalism, Regional \& Federal Studies, Vol.21, No.4-5, pp.539-559.

Buchanan, J.M. and Tullock, G. (1962), The Calculus of Consent. Logical Foundations of Constitutional Democracy. Ann Arbor: University of Michigan Press.

Burkhart, S., et al. (2008), A more efficient and accountable federalism? An analysis of the consequences of Germany's 2006 constitutional reform, German Politics, Vol.17, No.4, pp.522-540.

Bußjäger, P. (2004), Der Österreich-Konvent als Chance oder Inszenierung? - der Bundesstaat Österreich vor einem neuen Anlauf der Verfassungsreform, in Europäisches Zentrum für Föderalismusforschung (ed), Jahrbuch des Föderalismus 2004, pp.248-263. Baden-Baden: Nomos.

Choudhry, S. (ed) (2008), Constitutional Design for Divided Societies: Integration or Accommodation? Oxford: Oxford University Press.

Deschouwer, K. (2009), The Politics of Belgium. Governing a Divided Society. Basingstoke: Palgrave Macmillan.

Detterbeck, K. (2012), Multi-level Party Politics in Western Europe. Comparative Territorial Politics. New York: Palgrave Macmillan.

De Winter, L. and Baudewyns, P. (2009), Belgium: towards the breakdown of a nation-state in the heart of Europe? Nationalism and Ethnic Politics, Vol.15, No.3-4, pp.280-304.

Erk, J. (2008), Explaining Federalism. State, Society and Congruence in Austria, Belgium, Canada, Germany and Switzerland. London and New York: Routledge.

Farrell, H. and Héritier, A. (2007), Codecision and institutional change, West European Politics, Vol.30, No.2, pp.285-300.

Feld, L.P. (2010), Sinnhaftigkeit und Effektivität der deutschen Schuldenbremse, Perspektiven der Wirtschaftspolitik, Vol.11, No.3, pp.226-245.

Freiburghaus, D. (2002), Neuer Finanzausgleich und Föderalismusreform in der Schweiz, in Europäisches Zentrum für Föderalismus-Forschung (ed), Jahrbuch des Föderalismus 2002, pp.374-387. Baden-Baden: Nomos Verlagsgesellschaft.

Gagnon, A.-G. and Tully, J. (eds) (2001), Multinational Democracies. Cambridge: Cambridge University Press.

Geißler, R., et al. (eds) (2015), Das Teilen beherrschen. Analysen zur Reform des Finanzausgleichs 2019. Baden-Baden: Nomos.

Georgii, H. and Borhanian, S. (2006), Zustimmungsgesetze nach der Föderalismusreform. Berlin: Wissenschaftliche Dienste des Deutschen Bundestages.

Gerber, E. and Kollman, K. (2004), Introduction - authority migration: defining an emerging research agenda, PS: Political Science and Politics, Vol.37, No.3, pp.397-401.

Gerring, J. (2008), Case selection for case study analysis: qualitative and quantitative techniques, in J. Box-Steffensmeier, H. Brady and D. Collier (eds), Oxford Handbook of Political Methodology, pp.645-684. New York: Oxford University Press.

Hall, P.A. and Taylor, R.C.R. (1996), Political science and the three new institutionalisms, Political Studies, Vol.44, pp.936-957.

Hombrado, A. (2011), Learning to catch the wave? Regional demands for constitutional change in contexts of asymmetrical arrangements, Regional \& Federal Studies, Vol.21, No.4-5, pp.479-501. 
Hooghe, L. (2003), Belgium: from regionalism to federalism, in J. Coakley (ed.), The Territorial Management of Ethnic Conflict, pp.73-98. London: Frank Cass.

Höreth, M. (2007), Zur Zustimmungsbedürftigkeit von Bundesgesetzen: Eine kritische Bilanz nach einem Jahr Föderalismusreform I, Zeitschrift für Parlamentsfragen, Vol.38, No.4, pp.712-733.

Hrbek, R. (ed) (2003), Deutschland vor der Föderalismus-Reform. Tübingen: EZFF Selbstverlag.

Hueglin, T. (2000), From constitutional to treaty federalism: a comparative perspective, Publius: The Journal of Federalism, Vol.30, No.4, pp.137-153.

Hueglin, T. (2013), Treaty federalism as a model of policy making: comparing Canada and the European Union, Canadian Public Administration, Vol.56, No.2, pp.185-202.

Jeffery, C. (2009), Devolution in the United Kingdom: problems of a piecemeal approach to constitutional change, Publius, Vol.39, No.2, pp.289-313.

Kastrop, C., et al. (eds) (2010), Die neuen Schuldenregeln im Grundgesetz. Berlin: Berliner Wissenschafts-Verlag.

Keating, M. and McEwen, N. (2005), Introduction: devolution and public policy in comparative perspective, Regional and Federal Studies, Vol.15, No.4, pp.413-421.

Kropp, S. (2015), Federalism, people's legislation, and associative democracy, in C. Fraenkel-Haeberle, S. Kropp, F. Palermo and K.-P. Sommermann (eds), Citizen Participation in Multi-level Democracies, pp.48-66. Amsterdam, Leiden: Brill Nijhoff.

Kropp, S. (2010), The ubiquity and strategic complexity of grand coalition in the German federal system, German Politics (Special Issue: Kenneth Dyson and Thomas Saalfeld (eds.): Grand Coalition as Systemic Transformation? The German Experience), Vol.19, No.3/4, pp.286-311.

Lieberman, R.C. (2002), Ideas, institutions, and political order: explaining political change, American Political Science Review, Vol.96, No.4, pp.697-712.

Lorenz, A. (2011), Constitutional negotiations in federal reforms: interests, interaction orientation and the prospect of agreement, Regional \& Federal Studies. Special Issue: Federalism and Constitutional Change: Theoretical and Comparative Perspectives, Vol.21, No.4-5, pp.407-425.

Mahoney, J., et al. (2009), The logic of historical explanation in the social sciences, Comparative Political Studies, Vol.42, No.1, pp.114-146.

Mahoney, J. and Thelen, K. (eds) (2010), Explaining Institutional Change. Ambiguity, Agency, and Power. New York: Cambridge University Press.

Mayntz, R. and Scharpf, F.W. (1995), Der Ansatz des akteurszentrierten Institutionalismus, in R. Mayntz and F.W. Scharpf (eds), Gesellschaftliche Selbstregelung und politische Steuerung, pp.39-72. Frankfurt/M.: Campus.

McGarry, J. and Moore, M. (2005), Karl Renner, power sharing and non-territorial autonomy, in E. Nimni (ed), National Cultural Autonomy and Its Contemporary Critics, pp.74-94. London and New York: Routledge.

Meguid, B. (2005), Competition between unequals: the role of mainstream party strategy in niche party success, American Political Science Review, Vol.99, No.3, pp.347-359.

Mitchell, J. (2009), Devolution in the United Kingdom. Manchester: Manchester University Press.

Münch, U. and Zinterer, T. (2000), Reform der Aufgabenteilung zwischen Bund und Ländern: Eine Synopse verschiedener Reformansätze zur Stärkung der Länder 1985 bis 2000, Zeitschrift für Parlamentsfragen, Vol.3, pp.657-680.

Nee, V. (2005), New institutionalism, economic and sociological, in N. J. Smelser and R. Swedberg (eds), The Handbook of Economic Sociology, pp.49-74. Princeton, NJ: University of Princeton Press. 
Orren, K. and Skowronek, S. (1994), Beyond the iconography of order: notes for a "new institutionalism", in L.C. Dodd and C. Jillson (eds), The Dynamics of American Politics, pp.311-330. Boulder, CO: Westview Press.

Petersohn, B., et al. (2015), Negotiating territorial change in multinational states: party preferences, negotiating power and the role of the negotiation mode, Publius: The Journal of Federalism, pp.pjv016.

Pierson, P. (2000a), Increasing returns, path dependence, and the study of politics, American Political Science Review, Vol.94, No.2, pp.251-267.

Pierson, P. (2000b), The limits of design: explaining institutional origins and change, Governance: An International Journal of Policy and Administration, Vol.13, No.4, pp.475-499.

Pierson, P. (2004), Politics in Time. History, Institutions, and Social Analysis. Princeton, NJ: Princeton University Press.

Poirier, J. (2002), Formal mechanisms of intergovernmental relations in Belgium, Regional and Federal Studies, Vol.12, No.3, pp.24-54.

Radaelli, C.M. (2003), The Europeanization of public policy, in K. Featherstone and C.M. Radaelli (eds), The Politics of Europeanization, pp.27-56. Oxford: Oxford University Press. Russell, P.H. (2004), Constitutional Odyssey. Toronto: University of Toronto Press.

Scharpf, F.W. (1985), Die Politikverflechtungs-Falle: Europäische Integration und deutscher Föderalismus im Vergleich, Politische Vierteljahresschrift, Vol.26, pp.323-356.

Scharpf, F.W. (1997), Games Real Actors Play. Actor-centered Institutionalism in Policy Research. Boulder, CO: Westview Press.

Scharpf, F.W. (2000), Interaktionsformen: Akteurszentrierter Institutionalismus in der Politikforschung. Wiesbaden: VS Verlag für Sozialwissenschaften.

Scharpf, F.W. (2009), Föderalismusreform. Kein Ausweg aus der Politikverflechtungsfalle? Frankfurt a.M.: Campus Verlag.

Schmidt, V. (2008), Discursive institutionalism: the explanatory power of ideas and discourse, Annual Review of Political Science, Vol.11, No.1, pp.303-326.

Schneider, H.-P. (2013), Der neue deutsche Bundesstaat. Bericht über die Umsetzung der Föderalismusreform I. Baden-Baden: Nomos.

Scott, R.W. (2014), Institutions and Organizations. Ideas, Interests, and Identities (Vol.4). New York: Sage.

Shepsle, K.A. (2006), Rational choice institutionalism, in R.A.W. Rhodes, et al. (eds), The Oxford Handbook of Political Institutions, pp.23-38. Oxford: Oxford University Press.

Sturm, R. (2010), More courageous than expected? The 2006 reform of German federalism, in J. Erk and W. Swenden (eds), New Directions in Federalism Studies, pp.34-49. Abingdon: Routledge.

Swenden, W., et al. (2006), The politics of Belgium: institutions and policy under bipolar and centrifugal federalism, West European Politics, Vol.29, No.5, pp.863-873.

Swenden, W. and Maddens, B. (2009), Introduction. Territorial party politics in Western Europe: a framework for analysis, in W. Swenden and B. Maddens (eds), Territorial Party Politics in Western Europe, pp.1-30. New York: Palgrave Macmillan.

Taylor, C. (1992), Multiculturalism and the Politics of Recognition: An Essay. Princeton, NJ: Princeton University Press.

Toubeau, S. and Massetti, E. (2013), The party politics of territorial reforms in Europe, West European Politics, Vol.36, No.2, pp.297-316.

Tully, J. (1995), Strange Multiplicity. Constitutionalism in an Age of Diversity. Cambridge: Cambridge University Press. 